practised. In both barrows examples of the small segmented Egyptian faience beads were associated with the secondary burials. About eighty finds of Egyptian beads have now been made in Britain. The segmented type occurs in Egypt in the Eighteenth Dynasty from about 1600 B.c. onward, and is especially abundant at Tell el-Amarna (1380-50 в.c.). These beads have also been found in Hungary, Moravia, and Holland, and are thought to have reached Britain through Greece, travelling across Europe along the amber trade-route.

\section{Journal of Endocrinology}

A NEW journal, to be devoted to endocrinological subjects, under the title Journal of Endocrinology, has recently been founded. Its scope will be the publication of communications which advance knowledge concerning the internally secreting glands, the mode of their actions, the nature of their secretions, and the disorders of their functions. It is hoped that strong support will be given by contributors from abroad. There may be some who question the desirability of any step which might seem to accentuate the division of the field of medical and biological sciences into specialized departments and groups, but there can be little doubt as to the necessity for this new journal. The large and rapidly increasing amount of work on endocrinology published by British investigators, and the lack, hitherto, of a British journal specifically devoted to this subject, has led to the overcrowding of journals having other and more general interests. As a result, there has been increasing difficulty for endocrinologists who have work to publish, as well as for those who need ready access to the published work in this field. The foundation of this new journal was preceded by consultation with the editorial boards of a large number of journals, and it is significant that, without exception, these boards were in favour of the project. The control of the journal is vested in a Council of Management, and it will be edited by Prof. E. C. Dodds, who will be assisted by an editorial board consisting of Dr. P. M. F. Bishop, Prof. C. R. Harington, Prof. G. F. Marrian, Dr. A. S. Parkes, Dr. F. G. Young, and Dr. S. Zuckerman. Dr. R. L. Noble has been appointed as assistant editor. The journal will be published, in the first place, four times a year, and the subscription is $30 \mathrm{~s}$. or six dollars. The first number is due to appear during this month.

\section{Society of Rheology}

Tre Society of Rheology was founded in 1929 to further the study of the deformation and flow of matter in the broadest sense. The tenth annual meeting was held at the end of last year. At the banquet it was pointed out that expenses were not being met, and a discussion took place on the status of the Society and its publications programme. The policy favoured, almost unanimously, was to continue publication of the Rheology Leaflet and to enlarge it to include invitation review papers, while ordinary research papers would be published, as at present, in the Journal of Applied Physics. It was agreed that abstracts and bibliographies should be limited to those covering specific topics (not specified in the report) and that no attempt should be made at any complete covering of rheological literature. The co-operation of members was sought for increasing membership, but it was not mentioned how far this drive was to be international. The obvious method of circularizing authors of papers on rheological subjects, which does not seem to have been carried out in the past, was not mentioned. Rheology is one of those fields which include several sciencesphysics, chemistry and physical chemistry and, of late years, biology. Its importance and scope are only now beginning to be generally recognized. Given the necessary increase of support, the Society should then fulfil a very useful function. It would be especially valuable if its finances reached the point where it became possible to list (without full abstracting) all papers bearing on the subject. Now the Society is staking its reserves on the drive for increased membership in such manner that they will be exhausted in two years if the drive fails. It is to be hoped that the Society will receive the required support. Those interested should apply to the American Institute of Physics, 175 Fifth Avenue, New York. The subscription for associate members, who will receive the Rheology Leaflet, is 2.50 dollars.

\section{University of Minnesota Hydraulic Laboratory}

IN Engineering of May 26 is an illustrated article on the large hydraulic laboratory recently completed on the Mississippi River at St. Anthony Falls, Minneapolis, for the University of Minnesota. The laboratory is on Hennepin Island, which is joined to the banks of the river by a dam constructed for the purpose of power development at the falls, and it is designed to operate practically entirely by water diverted above the falls. There is a natural drop of fifty feet and the laboratory can handle for experimental purposes rates of flow in excess of 300 cusecs. Flows up to this amount can be accurately measured by volumetric basins. The laboratory consists of five units, namely, the main experimental laboratory, the hydraulic machinery and pump laboratory, the turbine testing laboratory, the large-scale volumetric tanks, and the lecture room and administration rooms. In the first of these units is a river model section where at present there is under construction a working model, $160 \mathrm{ft}$. long and $36 \mathrm{ft}$. wide, of the Mississippi in the vicinity of St. Anthony Falls. The lecture room has been arranged so that large quantities of water can be handled readily at the platform. Below the platform runs the main overhead supply flume of the laboratory, while above it is a head control room containing a constant-level reservoir situated in the tower above the auditorium. The experimental flume which runs through the main laboratory can be used for experiments with ship models.

\section{Improvements in Submarine Telephony in 1938}

IN the Engineering Supplement to the Siemens' Magazine of May, an account is given of three submarine cables laid last year to the order of the 
British Post Office and manufactured by Submarine Cables, Ltd. The first is an additional cable between Nevin (North Wales) and Howth (Eire). The second connects Dartmouth (Devonshire) and Guernsey and the third is laid between Guernsey and Jersey. The cables are of the concentric type insulated by paragutta and, with the exception of the sheathing, which is made suitable to the conditions prevailing round the British Isles, are similar to the cable laid three years ago from Australia across the Bass Strait. The C.S. Faraday left Greenwich in July 1938 carrying the Anglo-Eire and the two Channel Islands cables, weighing in all 1,440 tons. When the cable had been laid for ten miles from Nevin, a dense fog came on which completely obscured the buoys marking the course, but nevertheless the ship proceeded on its course and luckily sighted a marked buoy when the fog cleared. The submarine cables are operated by two carrier frequency systems the terminals of which are at Dublin and Nevin, with intermediate repeaters at Howth. The two concentric cables carry eighteen telegraph and fifteen telephone circuits. The laying of the Channel Islands cables presented little difficulty. A single core cable, which had formerly been part of an Atlantic telegraph cable, was relaid in 1914 between Compass Cove, near Dartmouth and Plemont, Jersey. In 1931 this was diverted into Saints Bay, Guernsey, to provide a telephone channel between England and Guernsey. The new cables provide two telephone circuits between England and Guernsey, and six telephone circuits between England and Jersey.

\section{Progress of the Grid}

THE report of the Central Electricity Board for the year 1938 is very satisfactory, although there was a slight reduction in the rate of increase at which electric power is being generated. For the first time since 1932, this rate of increase fell below 10 per cent per annum. The aggregate production is still substantially in excess of the estimates adopted by the Board and those made by the commissioners when planning the various grid schemes. The total output of electricity from public supply stations was 24,400 million units, an increase of nearly 1,500 million units over the previous year. Apparently the stimulus provided by the re-armament programme made up for the loss in demand of the shipbuilding, textile and other industries. At the end of 1938, the grid comprised 4,378 miles of transmission lines, nearly 3,000 miles of which operated at 132 kilovolts, the remainder operating at 66 kilovolts or less. The number of selected stations remained constant at 137 and their total installed capacity was more than $8 \frac{1}{4}$ million kilowatts. During the year, the Board investigated special air raid precautions. It was decided to provide a pool of switchgear, transformers and other equipment, which could readily be made available to replace, temporarily, apparatus that might be damaged. The research work into surges, defective lightning arresters and other troubles arising from atmospheric effects was continued throughout the year. Alterations were also made on switchgear so as to increase their rupturing capacity. The average cost of fuel per ton was 14s. 9d. in 1937 and $20 s .3 d$. in 1938. This increased cost of fuel more than counterbalanced the benefits which would otherwise have accrued to electricity consumers from the improved efficiency of generation.

\section{Electric Development in South Africa}

THE rapid economic development of South Africa during the last twenty years is illustrated by the remarkable growth that has taken place in the development of electricity both for industrial and domestic purposes. The extent to which the Union of South Africa is electrified is shown by the sales of electrical energy being 1,670 units per head of population per annum (excluding natives). This figure is twice that for the United States of America and nearly four times the corresponding figure for Great Britain. In a paper on "South African Activity" by H. A. Eastman, published in the Electrical Review for June 2, some of the reasons for this rapid and continuing growth are given. Three fifths of the total demand for electricity is due to the requirements for gold mining purposes. When the numerous mines in process of development are brought to the production stage, this will be greatly increased. The use of electricity for other industries and for domestic purposes is also increasing. The average price received by the generating stations is $0 \cdot 6 d$. per unit. The Electricity Act which came into force in 1922 provided for the establishment of an Electricity Control Board, which is the licensing and controlling authority for all private electricity undertakings. It also controls the Electricity Supply Commission, the members of which are appointed by the Government, but which, nevertheless, is free from parliamentary control. The Electricity Supply Commission operates its undertakings at neither a profit nor a loss and adjusts its charges accordingly. Other licencees are required to refund each year to their consumers, pro rata to their payments, 25 per cent of the surplus profits of the undertaking for that year.

\section{Baking Quality Tests for Flour}

Is 1934 the Imperial Bureau of Plant Breeding and Genetics published its first bibliography of papers on baking quality tests, which was an immediate success, and in a new supplement recently issued (Imperial Bureau of Plant Breeding and Genetics. Bibliography of Baking Quality Tests, Supplement. Pp. 32. Cambridge: School of Agriculture, 1939. 1s. 6d.) the Bureau has fully maintained the high standard it set itself in the earlier publication. A list of more than three hundred and thirty titles to original papers is given here, set out in alphabetical order. The list is remarkably complete and no really important communication appears to have been overlooked. One excellent feature of this bibliography which greatly commends it is the translation of the titles of the foreign publications into English. At the present time, extensive investigations are being made in Great Britain and abroad on the physical 